debatable, but this case seems to show that rheumatoid arthritis and the Australia antigen can coexist.-We are, etc.,

\section{S. Desche-Labarthe} R. CAQUeT Cl. LAROche

Hopital Cochin,

Paris

SIR,-Dr. C. J. Burrell and others (7 October, p. 23) stressed the occurrence in rheumatoid arthritis of false-positive results in tests for Australia or hepatitis-associated antigen (H.A.A.) using latex agglutination techniques. They suggested that the falsepositive results were due to rheumatoid factor in the serum.

Our experience with the search for H.A.A. (using countercurrent immunoelectro-osmophorosis) in the serum of 152 patients suffering from rheumatoid arthritis (84 of whom were positive for the rheumatoid factor) confirms the observation of Burrell $e t$ al. that there is no evidence of a relation between rheumatoid arthritis and a significant incidence of H.A.A. detectable by countercurrent immunoelectro-osmophorosis. The H.A.A. test was positive only in one rheumatoid-factor-negative patient with polyarthritis, who developed hepatitis two weeks after the serum was obtained.

Although we found in our series of 152 rheumatoid arthritis patients a significant incidence of positive tests for antinuclear factor $(22.6 \%$ of those postive and $8.8 \%$ of those negative for rheumatoid factor), the absence of H.A.A. in rheumatoid arthritis is in contrast to the high incidence of H.A.A. (by countercurrent immunoelectro-osmophorosis) reported in systemic lupus erythematosus. ${ }^{1-3}-$ We are, etc.,

A. BuRSSENS
J. DEQUEKER

W. ODEURS

Rheumatology Unit,

Belgium

1 Alarcón-Segovia, D. and Fishbein E., New England fourmal of Medicine, 1971 284, 448.

2 Alarcón-Seovia, D., Fishbein E., and DiazJouanen, Clinical and Experimental Immunology $197212,9$.

Ziegenfuss J. F Byrne E. B., Stolloff I. L. and Burka . F. Lancet 1972 1, 800.

\section{Intestinal Parasites and Au Antigen Transmission}

SIR,-Dr. M. Barbotin and Mr. J. L. Ondart (10 June, p. 653) suggested a possible association between hookworm and strongyloides infestation and the presence of Australia antigen in the blood. We have examined stool and blood samples from 300 randomly selected patients aged 10 years or over attending the University College Hospital, Ibadan, for the presence of hookworm ova or strongyloides larvae in the stool and for $\mathrm{Au}$ antigen in the blood (see Table). The overall incidence of Au antigenaemia is $2.3 \%$, and this is significantly lower than the incidence of $6.05 \%(P<0.05)$ found among 8,000 blood donors in Ibadan. ${ }^{1}$ However, these donors were all young adult males, and when comparable age and sex groups in the present series are compared the antigenaemia rate of $5 \%$ is found not to differ significantly from that found in the earlier blood donor series. Our sample of patients is therefore probably representative of the population at large.

\begin{tabular}{|c|c|c|c|c|c|c|c|c|}
\hline \multirow{2}{*}{$\begin{array}{l}\text { Age } \\
\text { (Years) }\end{array}$} & \multicolumn{2}{|c|}{ Number of Patients } & \multicolumn{2}{|c|}{ Hookworm Positive } & \multicolumn{2}{|c|}{ Strongyloides Positive } & \multicolumn{2}{|c|}{ Au Antigen Positive } \\
\hline & Male & Female & Male & Female & Male & Female & Male & Female \\
\hline $\begin{array}{r}0-10 \\
11-20 \\
21-30 \\
31-40 \\
41-50 \\
51-60 \\
61-70 \\
71 \text { and over } \\
\text { No age recorded }\end{array}$ & $\begin{array}{r}0 \\
18 \\
28 \\
31 \\
24 \\
18 \\
7 \\
3 \\
37\end{array}$ & $\begin{array}{r}1 \\
13 \\
29 \\
21 \\
20 \\
14 \\
6 \\
2 \\
18\end{array}$ & $\begin{array}{l}0 \\
9 \\
4 \\
5 \\
6 \\
7 \\
2 \\
2 \\
8\end{array}$ & $\begin{array}{r}0 \\
3 \\
12 \\
3 \\
2 \\
2 \\
1 \\
0 \\
5\end{array}$ & $\begin{array}{l}0 \\
7 \\
0 \\
5 \\
1 \\
5 \\
1 \\
0 \\
4\end{array}$ & $\begin{array}{l}0 \\
1 \\
2 \\
1 \\
1 \\
1 \\
0 \\
0 \\
1\end{array}$ & $\begin{array}{l}0 \\
1 \\
1 \\
2 \\
1 \\
0 \\
0 \\
0 \\
0\end{array}$ & $\begin{array}{l}0 \\
0 \\
0 \\
1 \\
0 \\
0 \\
0 \\
0 \\
1\end{array}$ \\
\hline Total & 166 & 124 & 43 & 28 & 23 & 7 & 5 & 2 \\
\hline $\begin{array}{l}\text { No age or sex } \\
\text { recorded .. }\end{array}$ & \multicolumn{2}{|c|}{10} & \multicolumn{2}{|c|}{1} & \multicolumn{2}{|c|}{$\mathbf{0}$} & \multicolumn{2}{|c|}{0} \\
\hline Total & \multicolumn{2}{|c|}{300} & \multicolumn{2}{|c|}{$72(24 \%)$} & \multicolumn{2}{|c|}{$30(10 \%)$} & \multicolumn{2}{|c|}{7.} \\
\hline
\end{tabular}

We found a substantially higher incidence of hookworm and strongyloides infestation than was found in Senegal. Our rate of $24 \%$ for hookworm was similar to that reported by Cowper from Ibadan, ${ }^{2}$ though the incidence of strongyloides infestation in the present series $(10 \%)$ seems to be significantly higher $(\mathrm{P}<0.01)$. Among the seven patients carrying $\mathrm{Au}$ antigen in their blood three were excreting hookworm ova and one was excreting strongyloides larvae, an incidence of $42.8 \%$ and $14.2 \%$ respectively. Chi-square analysis of the incidence of hookworm or strongyloides infestation and $\mathrm{Au}$ antigenaemia shows no evidence of a relationship between these two conditions $(P>0.3)$.

While there is little doubt that the incidence of Au antigenaemia is higher in the tropics than in temperate areas, and transmission by insects has been shown to be possible, ${ }^{3}$ we feel that the present evidence is insufficient to implicate hookworm or strongyloides as being concerned in the transmission of $\mathrm{Au}$ antigen, at least in the Ibadan environment.-We are, etc.,

\[ \times /, \begin{array}{r}\text { E. A. LEWIS } \\ \text { D. MONTEFIORE } \\ \text { J. A. SMITH }\end{array} \]
A. O. SOGBETUN
University College Hspital,
badan, Nigeria
Francis, T. I., and Smith, J. A., British Medical
fournal, i971, 4, 683.
Cowper, S. G., West African Medical fournal,
1966, 15, 203., Ogunba, E. O., and Francis, T. I.,
Smith, J. A., Ogure, 1972, 237, 231.
Nature, 1972, 237, 231 .

Trichuris Infestations and Difetarsone

SIR,-Monoinfestations with Trichuris trichiura were rare until anthelmintics selectively active against Ascaris lumbricoides, hookworms, and Strongyloides stercoralis made evident the presence of $T$. trichiura. Difetarsone (14 October, p. 73) is specifically effective against $T$. trichiura, like piperazine against $A$. lumbricoides and bephenium against $A$. duodenale. Polyparasitosis, with its multiple clinical manifestations, is increasingly encountered in temperate regions. Several broad-spectrum anthelmintics have been developed, but few completely remove the Ancylostoma and Trichuris burden.

Mebendazole (methyl (5-benzoylbenzimidazol-2-yl) carbamate) has been studied in children and adults with mono- and polyparasitosis in Africa, ${ }^{12}$ Asia, ${ }^{3}$ Europe, ${ }^{4-6}$ and North, ${ }^{7}$ Central, ${ }^{8}$ and South America. ${ }^{10} \mathrm{~A}$ single $100-\mathrm{mg}$ tablet radically cures infestation with Enterobius vermicularis and $A$. lumbricoides. A standard $100-\mathrm{mg}$ dose given twice daily for three consecutive days is virtually $100 \%$ effective against Necator americanus, $A$. duodenale, and T. trichiura, and shows high promise against Taenia solium and $T$. saginata. Activity against $S$. stercoralis, though significant, is less regular. Because of its potency and its broad spectrum of anthelmintic action, coupled with total absence of side effects and standard dosage, irrespective of the patient's age or weight, mebendazole is of special value in all patients with single or multiple helminth infestations. - We are, etc., Department of Microbiology,
University of Leuven,

J. VANDEPITTB

Institute of Tropical Medicine,

D. THIENPONT

1 Vandepitte, J., Gatti, F., Lontie M., Krubwa, F., Nguete, M., and Thienpont, D., Bulletin de la Société de Pathologie Exotique. In press. Gatti, F., Krubwa, F., Lontie, M., Vandepitte, I., and Thienpont, D., Proceedings of the VIIth Intarnational Congress, of Chemotherapy,
Prague (Czechoslovakia), 23-28 August 1971.

Prague (Czechoslovakia), 23-28 August 1971.
Baneriee, D., Prakash, O and Kaliyugaperumal,
Y. Indian fournal of Medical Research, 1972, 60, India. 562 .

4 Brugmans, J.; Thienpont, D., van Wijngaarden, I., Vanparijs, O., Schuermans, V., and Lauwers, ciation, 1971, 217, 313 .

5 Fierlafij, E., Bruxelles-Médical, 1971, 51, 605. Klein, E., Deutsche medizinische Wochenschrift $1973,97,1215$.

7 Sargent, R. G., personal communication. Chavarria, P. A., 47th Annual Meeting of the Chaia, G. M-10 Nétene, Fo, Chiari, L., de Moura Araujo, S., and Barbosa de Abreu, I., Folha Médica, 1972, 64, 139

Médica, 1971, 63, 843 da Cunha, A., Folhe

\section{Myxoedema and Retention of Urine}

SIR,-Renal function is often moderately affected in hypothyroidism, ${ }^{1}$ probably owing to interstitial infiltration, enlargement of the basal tubular membrane, ${ }^{2}$ and the low renal perfusion brought about by the illness. ${ }^{3}$ So far as we know there have been no reports of hypothyroidism presenting as renal failure resulting from urinary obstruction due to vesical paresis caused probably by myxoedematous hypotonia of the smooth musculature. We report here a case of this kind.

Six months before being admitted to hospital a 67-year-old woman developed character changes and urinary retention. Daily catheterization was required. Later constipation, a changed tone of voice, mental confusion, and deafness also developed and became progressively worse. On admission the patient was typically myxoedematous. The bladder could be palpated in the abdomen, the Achilles tendon reflex was slow, the E.C.G. presented low voltages, and the E.E.G. slow, diffuse, predominantly frontal waves. Neurological examinaation was otherwise normal. Blood examination howed: haemoglobin $7.2 \mathrm{~g} / 100 \mathrm{ml}$, leucocytes $9,200 / \mathrm{mm}^{3}$, protein-bound iodine $0.4 \mu \mathrm{g} / 100 \mathrm{ml}$, 